\title{
Synthesis and Characterizations of Zinc Oxide Nanoparticles for Antibacterial Applications
}

\section{Getie S, Belay A*, Chandra Reddy AR and Belay Z}

Adama Science and Technology University, Applied Physics Program, Ethiopia

\begin{abstract}
In this study various shapes and sizes of the wurtzite structure of $\mathrm{ZnO}$ nanoparticles were synthesised via a wet chemical method for antibacterial applications. The synthesised ZnO NPs were also modified using biologically active compound, caffeine. The $\mathrm{ZnO}$ nanoparticles were investigated by XRD, SEM, FTIR, UV-Vis and Fluorescence spectroscopy. The average crystallite size of the ZnO NPs using XRD was within the ranges of 28.09-31.86 nm. The shape of $\mathrm{ZnO} N P s$ synthesised from $\mathrm{Zn}\left(\mathrm{NO}_{3}\right)_{2} \cdot 6 \mathrm{H}_{2} \mathrm{O}, \mathrm{ZnCl}_{2}$ and $\mathrm{Zn}\left(\mathrm{CH}_{3} \mathrm{COO}\right)_{2} \cdot 2 \mathrm{H}_{2} \mathrm{O}$ grain, spherical and rod-like respectively. The variations in size and shape of $\mathrm{ZnO}$ NPs are due to the difference in precursors and calcinations temperature. The absorption peak of the $\mathrm{ZnO} N P s$ was observed at $278 \mathrm{~nm}, 374 \mathrm{~nm}$ and $378 \mathrm{~nm}$ for $\mathrm{ZnCl}, \mathrm{Zn}$ $\left(\mathrm{NO}_{3}\right)_{2} \cdot 6 \mathrm{H}_{2} \mathrm{O}$ and $\mathrm{Zn}\left(\mathrm{CH}_{3} \mathrm{COO}\right)_{2} \cdot 2 \mathrm{H}_{2} \mathrm{O}$ respectively. The FTIR peaks due to vibrational phonons of $\mathrm{ZnO} \mathrm{NPs}$ also confirm the successful production of $\mathrm{ZnO}$ nanoparticles. The emission spectra of $\mathrm{ZnO}$ NPs were observed in ultraviolet due to the electronic transition from conduction band edge to valence band, and visible emission band due to defects that are related to deep level emissions. The synthesised ZnO NPs were applied for antibacterial activity against $S$. aureus and $E$. coli bacteria using agar disc diffusion method. All the three $\mathrm{ZnO}$ Nps performed better antibacterial activity than the standard antibiotics and also $S$. aureus was shown to be more sensitive to ZnO NPs than E. coli.
\end{abstract}

Keywords: Zinc oxide nanoparticles; Spectroscopic techniques; Antibacterial activities

\section{Introduction}

Zinc oxide NPs has unique physical and chemical properties, such as high chemical stability, high electrochemical coupling coefficient, broad range of radiation absorption and high photostability, is a multifunctional material $[1,2]$. It has tremendous scientific and technological interest due to direct wide band gap energy $(3.37 \mathrm{eV})$, large exciton-binding energy $(60 \mathrm{meV})$ and high thermal and mechanical stability at room temperature make it attractive for potential use in electronics, optoelectronics and laser technology $[3,4]$. The piezo- and pyroelectric properties of $\mathrm{ZnO}$ mean that it can be used as a sensor, converter, energy generator and photocatalyst in hydrogen production $[5,6]$. Because of its hardness, rigidity and piezoelectric constant it is an important material in the ceramics industry, while its low toxicity, biocompatibility and biodegradability make it a material of interest for biomedicine and in pro-ecological systems [7-9].

Several methods have been reported in the literature for synthesis of $\mathrm{ZnO}$ nanoparticles, categorized into either chemical or physical methods, such as nanolithography, physical vapour deposition (PVD), chemical vapour deposition, spray conversion processing, sol-gel process, and precipitation method [10-17]. Among the various methods, precipitation is one of the most important methods to prepare the nanoparticles; the method reduces the temperature of the reaction where homogenous mixtures of the reagents precipitate. It is simple method for the synthesis of nanopowders of metaloxides, which are highly reactive in low temperature sintering.

Metal oxides NPs have been studied extensively to explore their utility as a potential antibacterial agent. The deposition of nanoparterticles on the surface of bacteria or accumulation of NPs either in cytoplasm in the periplasmic region causes disruption of cellular function or disruption and disorganization of membranes $[18,19]$. Similarly, it has been suggested that $\mathrm{ZnO}$ NPs are able to slow down the growth of bacteria due to disorganization of the bacteria membranes, which increases membrane permeability leading to accumulation of nanoparticles in the bacterial membrane and cytoplasmic regions of the cells. The different protective mechanism of $\mathrm{ZnO}$ NPs has been suggested that $\mathrm{ZnO} \mathrm{Nps}$ may protect intestinal cells from bacterial infection by inhibiting the adhesion and internalization of bacteria by preventing the increase of tight junction permeability and modulating cytokine [20]. Moreover, the electrostatic attraction between negatively charged bacterial cells and positively charged particles is crucial for the activity of nanoparticles bactericidal materials. This interaction not only inhibits the bacterial growth but also induces the reactive oxygen species (ROS) generation, which leads to cell death [21-23]. The antimicrobial activity of zinc oxide nanoparticles have been studied against Gram-negative bacteria such as Pseudomonas aeruginosa, campylobacter jejuni, Escherichia coli and Gram-positive bacteria such as Bacillus subtillis and Staphylococcus aureus [24].

In this research, the synthesis of different shape, sizes and morphology of $\mathrm{ZnO}$ NPs were synthesised using various precursors via wet chemical method for the inhibition of $S$. aureus and E. coli bacteria. In addition, surface modification of $\mathrm{ZnO}$ NPs was also investigated using biologically active compound, caffeine. The techniques are relatively inexpensive and do not require sophisticated laboratory equipments. In addition, slight variation in precursors or process parameters can produce different morphologies that can be applied in different technological fields.

*Corresponding author: Abebe Belay, Adama Science and Technology University, Applied Physics Program, Ethiopia, Tel: 251911712766; E-mail: abebebelay96@gmail.com

Received November 02, 2017; Accepted November 21, 2017; Published November 29, 2017

Citation: Getie S, Belay A, Chandra Reddy AR, Belay Z (2017) Synthesis and Characterizations of Zinc Oxide Nanoparticles for Antibacterial Applications. J Nanomedic Nanotechnol S8: 004. doi:10.4172/2157-7439.S8-004

Copyright: (C) 2017 Getie S, et al. This is an open-access article distributed unde the terms of the Creative Commons Attribution License, which permits unrestricted use, distribution, and reproduction in any medium, provided the original author and source are credited. 


\section{Materials and Methods}

\section{Materials}

All the chemicals used in this experiments were analytical grade and used without any further purification. The precursor chemicals are zinc nitrate hexahydrate (Himedia, India), sodium hydroxide (Alpha chemika, India), zinc chloride (Neolab, India), zinc acetate dihydrate (Uni-Chem, India), caffeine (Sigma-Aldrich, Germany). And other solvents such as deionized water, nitric acid and di-methyl sulphoxide (DMSO).

\section{Synthesis methods}

During synthesis of $\mathrm{ZnO}$ NPs the main parameters such as, size of the particle, chemical composition, crystalline structure and morphology must be controlled [25]. In this study, wet chemical method was used for the preparation of $\mathrm{ZnO}$ nanoparticles. The synthesis procedures for grain like $\mathrm{ZnO}$ nanoparticles were conducted according to the procedures developed [26]. About $12 \mathrm{~g}$ of $\mathrm{Zn}\left(\mathrm{NO}_{3}\right)_{2} \cdot 6 \mathrm{H}_{2} \mathrm{O}$ was dissolved in $100 \mathrm{ml}$ of deionized water in a beaker and stirred for 25 minutes using magnetic stirrer. The resulting solution was heated under constant stirring, at the temperature of $70^{\circ} \mathrm{C}$. Subsequently, $3.2 \mathrm{~g}$ of $\mathrm{NaOH}$ was also dissolved in $30 \mathrm{ml}$ of deionized water in a separate beaker and stirred for 10 minute. After this, a solution of $\mathrm{NaOH}$ was slowly added drop by drop into the beaker containing the $\mathrm{Zn}\left(\mathrm{NO}_{3}\right)_{2} \cdot 6 \mathrm{H}_{2} \mathrm{O}$ solution under stirring condition. The suspension formed with the dropping of $\mathrm{NaOH}$ alkaline aqueous solution to the $\mathrm{Zn}\left(\mathrm{NO}_{3}\right)_{2} \cdot 6 \mathrm{H}_{2} \mathrm{O}$ solution was kept stirred for two hours at the temperature of $70^{\circ} \mathrm{C}$. The mixed solution was settled under normal air condition for few hours, and filtered using whatman filter paper. The filtered sample was dried in oven at $160^{\circ} \mathrm{C}$ for $31 / 2 \mathrm{~h}$, and calcinated at $300^{\circ} \mathrm{C}$ for $5 \mathrm{~h}$ in a muffle furnace.

The synthesis procedures for spherical zinc oxide nanoparticles were conducted according to the procedures developed [27]. About 20 $\mathrm{g}$ of zinc chloride was dissolved in $100 \mathrm{ml}$ of deionized water in a beaker and stirred for 45 minutes using magnetic stirrer at the temperature of $90^{\circ} \mathrm{C}$. Similarly, $7.27 \mathrm{~g}$ of $\mathrm{NaOH}$ was dissolved in $100 \mathrm{ml}$ of deionized water in a separate beaker and stirred for 20 minutes. $58 \mathrm{ml}$ solution of sodium hydroxide was added to the beaker containing $\mathrm{ZnCl}_{2}$ solution with constant stirring. The aqueous solution turned into a milky white colloid without any precipitation. The reaction was allowed to proceed for $2 \mathrm{~h}$ after complete addition of sodium hydroxide. The solution was allowed to settle and filtered using whatman filter paper. The filtered sample was allowed to dry in oven at $160^{\circ} \mathrm{C}$ for $7 \mathrm{~h}$, and calcinated at $200^{\circ} \mathrm{C}$ for $2 \mathrm{~h}$ in a muffle furnace. Finally, the material was grinded using mortar and pestle.

The synthesis for nanorod of zinc oxide nanoparticles were conducted according to the procedures developed [28]. About $15 \mathrm{~g}$ of $\mathrm{Zn}\left(\mathrm{CH}_{3} \mathrm{COO}\right)_{2} \cdot 2 \mathrm{H}_{2} \mathrm{O}$ was placed into a crucible and calcinated at $400^{\circ} \mathrm{C}$ for $12 \mathrm{~h}$ in a muffle furnace without any special atmospheric condition. Finally, the material was grinded using mortar and pestle.

\section{Modification of $\mathrm{ZnO}$ nanoparticles with caffeine}

About $4 \mathrm{~g}$ of zinc oxide nanoparticles and $1.5 \mathrm{~g}$ of caffeine was dissolved in $60 \mathrm{ml}$ of di-methyl sulphoxide (DMSO) in a beaker. The mixed solution was stirred for $5 \mathrm{~h}$ using magnetic stirrer at the temperature of $40^{\circ} \mathrm{C}$. After this, the solution was settled under normal air condition and filtered using whatman filter paper. Finally, the filtered sample was dried in oven for $8 \mathrm{~h}$ at $160^{\circ} \mathrm{C}$.

\section{Methods of characterization}

The X-ray powder diffraction patterns of the $\mathrm{ZnO}$ nanoparticless were recorded using X-ray Diffractometer (PANalytical X'PERTPRO Diffractometer) equipped with nickel filtered $\mathrm{Cu}-\mathrm{Ka}{ }_{1}$ radiation $\left(\lambda=1.5406 \mathrm{~A}^{\circ}\right)$ operating at $45 \mathrm{KV}$ and $30 \mathrm{~mA}$. The data have been collected in the scan range $(2 \theta)$ from $10-100^{\circ}$. The average crystallite size of $\mathrm{ZnO}$ nanoparticles were calculated using Debye Scherer formula according to eqn. (1) [29].

$$
D=\frac{0.9 \lambda}{\beta \cos \theta}
$$

Where $\mathrm{D}$ is average crystallite size, $\lambda$ is wavelength of incident beam (1.5406 $\AA$ ), $\beta$ is full width at half-maximum (FWHM) in radians and $\theta$ is scattering angle in degrees. The lattice constants ' $a$ ' and ' $c$ ' and the spacing ' $\mathrm{d}_{\mathrm{hkl}}$, for wurtzite structure of $\mathrm{ZnO}$ have been calculated according to eqns. (2) and (3).

$$
\begin{aligned}
& a=\sqrt{\frac{1}{3}} \frac{\lambda}{\sin \theta} \text { and } c=c=\frac{\lambda}{\sin \theta} \\
& d_{h k l}=\frac{a c}{2} \sqrt{\frac{3}{c^{2}\left(h^{2}+h k+k^{2}\right)+3 \frac{(a l)^{2}}{4}}}
\end{aligned}
$$

The morphological feature of the modified and unmodified $\mathrm{ZnO}$ NPs were determined by using Scanning Electron Microscopy (SEM), using electron beam energy of $10 \mathrm{KV}$ and $15 \mathrm{KV}$. The $\mathrm{ZnO}$ NP powder is mounted on a sample holder followed by coating with a conductive metal. Then, the sample was scanned with focused fine beam of electrons. The surface characteristics of the sample were obtained from the secondary electrons emitted from the sample surface.

The UV-Vis absorption peaks of ZnO NPs were recorded with UV-Vis spectroscopy (PerkinElmer, Lambda 950 UV/VIS/NIR Spectrophotometer) in the wavelength region of $260-600 \mathrm{~nm}$ at room temperature. The $\mathrm{ZnO}$ nanoparticles were dissolved in DMSO and its absorbance measured using $1 \mathrm{~cm}$ quartz cuvette. The ASC files were collected by computer interfaced with the instrument. Finally, the absorption spectra of $\mathrm{ZnO} \mathrm{NPs}$ were analyzed using origin 8 software.

The emission spectra of $\mathrm{ZnO}$ NPs were measured with fluorescence spectroscopy (Fluoromax-4 Spectrofluorometer) at room temperature. Before the measurements, the NPs samples were dissolved in dimethyl sulphoxide (DMSO) and stirred until it dissolved. The emission spectra of the sample were measured by $1 \mathrm{~cm}$ quartz cuvette. The excitation wavelength of the samples were performed at $310 \mathrm{~nm}, 275$ $\mathrm{nm}$ and $355 \mathrm{~nm}$ for salt precursors of $\mathrm{Zn}\left(\mathrm{CH}_{3} \mathrm{COO}\right)_{2} .2 \mathrm{H}_{2} \mathrm{O}, \mathrm{ZnCl}_{2}$ and $\mathrm{Zn}\left(\mathrm{NO}_{3}\right)_{2} \cdot 6 \mathrm{H}_{2} \mathrm{O}$ and emission spectra were measured in the wavelength region of 300-500 $\mathrm{nm}$ respectively. The slit width of the instrument was adjusted to $5 \mathrm{~nm}$.

The vibrational phonon and the quality of $\mathrm{ZnO}$ NPs were also characterized by Fourier Transform Infrared Spectroscopy (Perkin Elmer, Spectrum 65 FTIR) in the wavenumber region of $4000-400$ $\mathrm{cm}^{-1}$ according to the procedures reported [30]. The FTIR spectra measurements of the $\mathrm{ZnO}$ nanoparticles were performed by putting the powder $\mathrm{ZnO}$ nanoparticles on $\mathrm{KBr}$ pellet.

\section{Antibacterial activity test}

The antibacterial activity of the zinc oxide nanoparticles on grampositive (S. aureus) and gram-negative (E. coli) bacteria were tested by agar disc diffusion method according to the procedures reported [29]. Microbial strains were grown aerobically in nutrient broth for 24 
Citation: Getie S, Belay A, Chandra Reddy AR, Belay Z (2017) Synthesis and Characterizations of Zinc Oxide Nanoparticles for Antibacterial Applications. J Nanomedic Nanotechnol S8: 004. doi:10.4172/2157-7439.S8-004

Page 3 of 8

$\mathrm{h}$ at $37^{\circ} \mathrm{C}$ until the turbidity of bacterial suspensions was achieved to $1.5 \times 10^{8} \mathrm{CFU} \mathrm{mL} \mathrm{m}^{-1}$ by comparison with the $0.5 \mathrm{McF}$ arland Standard. The disc diffusion assay was carried out by swabbing each test strain on Mueller-Hinton ( $\mathrm{MH}$ ) agar plate using the 1/10 dilution of the microbial suspensions. Subsequently, about $300 \mathrm{mg}, 450 \mathrm{mg}$ and 600 $\mathrm{mg}$ of each $\mathrm{ZnO}$ nanoparticles was synthesised from the salt precursors $\mathrm{ZnCl}, \mathrm{Zn}\left(\mathrm{NO}_{3}\right)_{2} \cdot 6 \mathrm{H}_{2} \mathrm{O}$ and $\mathrm{Zn}\left(\mathrm{CH}_{3} \mathrm{COO}\right)_{2} \cdot 2 \mathrm{H}_{2} \mathrm{O}$ were dispersed separately in $30 \mathrm{ml}$ of dimethyl sulfoxide (DMSO) and stirred for 2 $\mathrm{h}$ using magnetic stirrer. Sterile standard filter paper discs $(4 \mathrm{~mm}$ in diameter) were impregnated with sterile aqueous suspensions of $\mathrm{ZnO}$ at $10,15,20 \%$ concentrations and placed onto the inoculated plates using sterile forceps. The standard antibiotic drug vancomycin and the null filter paper disc were used as control positive and control negative, respectively. Then the plates were incubated at $37^{\circ} \mathrm{C}$ for 24 hrs. All measurements were performed in triplicate. Finally, the zone of inhibition formed around the discs was measured in millimetres ( $\mathrm{mm})$ and recorded.

\section{Results and Discussion}

\section{XRD patterns of $\mathrm{ZnO}$ nanoparticles}

Figure $1 \mathrm{a}$ and $\mathrm{lb}$ shows the XRD pattern of $\mathrm{ZnO}$ nanoparticles synthesised using $\mathrm{Zn}\left(\mathrm{NO}_{3}\right)_{2} \cdot 6 \mathrm{H}_{2} \mathrm{O}$ and $\mathrm{Zn}\left(\mathrm{CH}_{3} \mathrm{COO}\right)_{2} \cdot 2 \mathrm{H}_{2} \mathrm{O}$ respectively. The diffraction peaks of $\mathrm{ZnO}$ NPs correspond to (100), (002), (101), (102), (110), (103), (112) and (201) planes [28]. The 2-theta values of (100), (002) and (101) lines of Figure 1a and $1 \mathrm{~b}$ of the crystal planes are located at $31.77,34.422$ and $36.253^{\circ}$. Some peaks were also noticed which associated with impurity on $\mathrm{ZnO}$ NPs synthesised from $\mathrm{Zn}\left(\mathrm{NO}_{3}\right)_{2} \cdot 6 \mathrm{H}_{2} \mathrm{O}$. The average crystallite size of the $\mathrm{ZnO}$ NPs calculated using Debye Scherer formula was about $31.86 \mathrm{~nm}$ and $28.09 \mathrm{~nm}$ for salt precursors of zinc acetate dihydrate and zinc nitrate hexahydrate respectively. All $\mathrm{ZnO}$ NPs possess wurtzite crystalline structure with lattice parameters $(\mathrm{a}=0.3233 \mathrm{~nm}$ and $\mathrm{c}=0.5606$ tai $\mathrm{nm})$. The obtained results are in a good agreement with previously reported [31]. The variation in the average crystallite size of $\mathrm{ZnO}$ NPs may be due to the variation of precursors and calcination temperature. The summary of the $\mathrm{XRD}$ analysis of $\mathrm{ZnO}$ NPs synthesised from $\mathrm{Zn}\left(\mathrm{CH}_{3} \mathrm{COO}\right)_{2} \cdot 2 \mathrm{H}_{2} \mathrm{O}$ and $\mathrm{Zn}\left(\mathrm{NO}_{3}\right)_{2} \cdot 6 \mathrm{H}_{2} \mathrm{O}$ is given in Table $1 \mathrm{a}$ and $1 \mathrm{~b}$ respectively.

\section{SEM analysis}

Figure 2a-2c shows the SEM images of $\mathrm{ZnO}$ NPs synthesised using

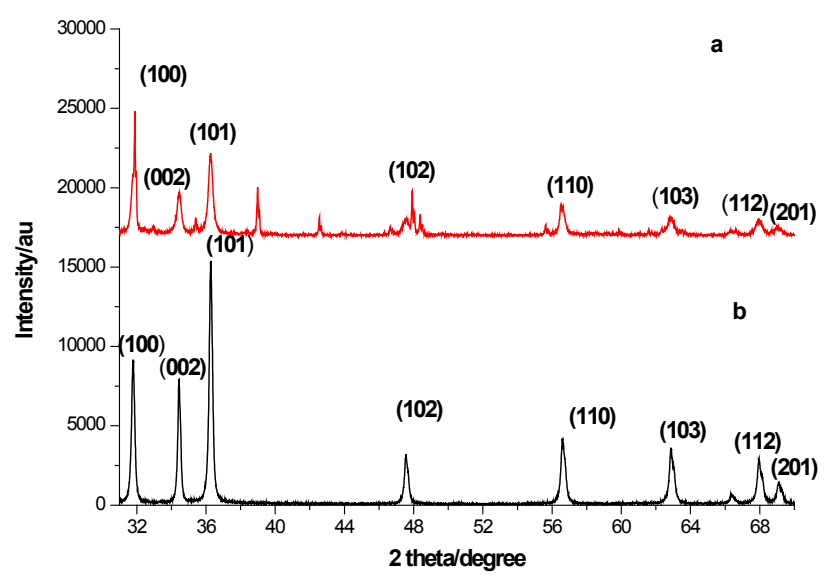

Figure 1: XRD pattern of ZnO nanoparticles synthesised using a) Zinc acetate dehydrate at calcinations temperature $400^{\circ} \mathrm{C}$ b) Zinc nitrate hexahydrate at calcinations temperature $300^{\circ} \mathrm{C}$.

\begin{tabular}{|c|c|c|c|c|}
\hline \multicolumn{5}{|c|}{ (A) } \\
\hline hkl & $2 \theta$ (degree) & FWHM (degree) & Crystallite size (nm) & $\mathrm{D}(\mathrm{nm})$ \\
\hline 100 & 31.938 & 0.22264 & 37.13 & \multirow{8}{*}{31.86} \\
\hline 002 & 34.598 & 0.20203 & 41.20 & \\
\hline 101 & 36.247 & 0.22781 & 36.71 & \\
\hline 102 & 47.546 & 0.28489 & 30.59 & \\
\hline 110 & 56.536 & 0.31917 & 28.27 & \\
\hline 103 & 62.845 & 0.34739 & 26.81 & \\
\hline 112 & 67.835 & 0.35583 & 26.91 & \\
\hline 201 & 69.154 & 0.35376 & 27.28 & \\
\hline \multicolumn{5}{|c|}{ (B) } \\
\hline 100 & 31.897 & 0.23954 & 34.50 & \multirow[t]{8}{*}{28.09} \\
\hline 002 & 34.453 & 0.27754 & 29.98 & \\
\hline 101 & 36.226 & 0.28338 & 29.51 & \\
\hline 102 & 47.917 & 0.25531 & 34.06 & \\
\hline 110 & 56.556 & 0.34524 & 26.14 & \\
\hline 103 & 62.927 & 0.39805 & 23.41 & \\
\hline 112 & 67.934 & 0.41377 & 23.17 & \\
\hline 201 & 69.135 & 0.40131 & 24 & \\
\hline
\end{tabular}

Table 1: The X-ray diffraction parameters and crystallite size of $\mathrm{ZnO}$ nanoparticles synthesised using a) zinc acetate dihydrate and b) zinc nitrate hexahydrate.

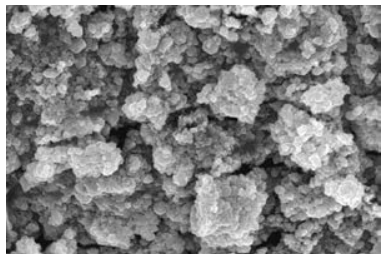

a) Unmodified $\mathrm{ZnO} \mathrm{NP}$

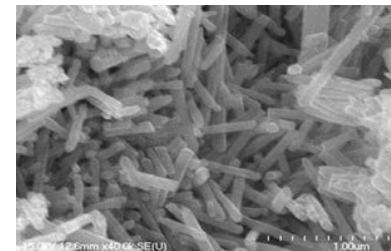

b) Unmodified $\mathrm{ZnO} \mathrm{NPs}$

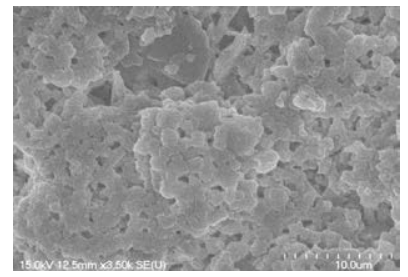

c) Unmodified $\mathrm{ZnO} \mathrm{NPs}$

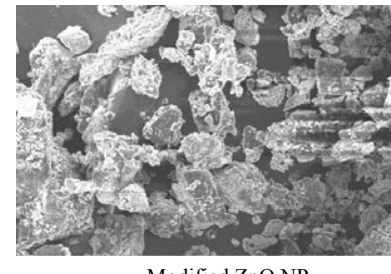

Modified ZnO NP

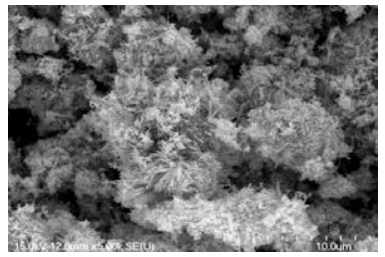

Modified $\mathrm{ZnO}$ NPs

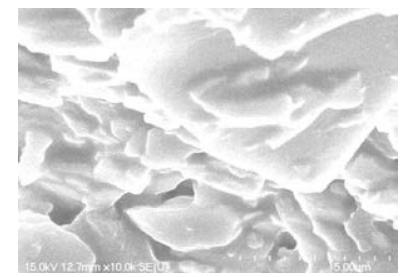

Modified ZnO NPs
Figure 2: SEM images of unmodified and modified $\mathrm{ZnO}$ NPs synthesised from a) zinc nitrate hexahydrate, b) zinc acetate dihydrate and c) zinc chloride

$\mathrm{Zn}\left(\mathrm{NO}_{3}\right)_{2} \cdot 6 \mathrm{H}_{2} \mathrm{O}, \mathrm{Zn}\left(\mathrm{CH}_{3} \mathrm{COO}\right)_{2} \cdot 2 \mathrm{H}_{2} \mathrm{O}$ and $\mathrm{ZnCl}_{2}$ respectively. The morphology of $\mathrm{ZnO}$ nanoparticle synthesised from $\mathrm{Zn}\left(\mathrm{NO}_{3}\right)_{2} \cdot 6 \mathrm{H}_{2} \mathrm{O}$ was grain (Figure 2a). On the other hand, the morphology of $\mathrm{ZnO}$ nanoparticle synthesised from $\mathrm{Zn}\left(\mathrm{CH}_{3} \mathrm{COO}\right)_{2} \cdot 2 \mathrm{H}_{2} \mathrm{O}$ and $\mathrm{ZnCl}_{2}$ were nanorod and spherical types. As shown in Figure 2a-2c, the SEM images of the NPs have different shape and size which are similar with XRD results. The variation of the shape and size of the $\mathrm{ZnO} N P$ s is due to the difference in their precursors, calcination temperature and preparation 
processes [30,31]. Similarly, on the right side of Figure $2 \mathrm{a}-2 \mathrm{c}$ show the surface modification of $\mathrm{ZnO}$ NPs using biologically active compound, caffeine. Disaggregation of $\mathrm{ZnO} \mathrm{NPs}$ and adsorption of caffeine on the surface alter the typical environment of the nanoparticles. The adsorption of negatively CAF onto ZnO NPs makes the surface negatively charged resulting repulsion between nanoparticles leading to dispersion of already aggregate nanoparticles.

\section{The UV-Vis absorption pattern of $\mathrm{ZnO}$ nanoparticles}

Figure $3 \mathrm{a}-3 \mathrm{c}$ shows the $\mathrm{UV}$-Vis absorption spectra of $\mathrm{ZnO}$ nanoparticles synthesised using $\mathrm{Zn}\left(\mathrm{NO}_{3}\right)_{2} \cdot 6 \mathrm{H}_{2} \mathrm{O}, \mathrm{Zn}\left(\mathrm{CH}_{3} \mathrm{COO}\right)_{2} \cdot 2 \mathrm{H}_{2} \mathrm{O}$, $\mathrm{ZnCl}_{2}$ at different calcinations temperatures. The absorption peak of $\mathrm{ZnO}$ nanoparticles were observed at $278 \mathrm{~nm}, 374 \mathrm{~nm}$ and 378 $\mathrm{nm}$ at calcinated temperature of 200,300 and $400^{\circ} \mathrm{C}$ respectively. As temperature increases, the peak absorbance wavelength become red shifted due to decreasing quantum confinement with increasing particle size. These peaks are due to electronic transition from deep level of valence band to conduction band. The UV-Vis absorption peak variation among the $\mathrm{ZnO}$ nanoparticles are due to the difference in their size and shape, which results due to a variety of precursors and calcination temperature $[32,33]$.

\section{Fourier Transform Infrared Spectroscopy of $\mathrm{ZnO}$ nanoparticles}

Figure $4 \mathrm{a}-4 \mathrm{c}$ shows the FT-IR spectra of $\mathrm{ZnO}$ nanoparticles synthesised from $\mathrm{Zn}\left(\mathrm{NO}_{3}\right)_{2} \cdot 6 \mathrm{H}_{2} \mathrm{O}, \mathrm{ZnCl}_{2}$ and $\mathrm{Zn}\left(\mathrm{CH}_{3} \mathrm{COO}\right)_{2} \cdot 2 \mathrm{H}_{2} \mathrm{O}$ respectively. The FT-IR spectrum of the NPs contains serious of peaks from 1000 to $4000 \mathrm{~cm}^{-1}$ corresponding to carboxylate (COO) and hydroxyl $(\mathrm{O}-\mathrm{H})$ impurities in the materials. The broad band around $3500 \mathrm{~cm}^{-1}$ assigned to $\mathrm{O}-\mathrm{H}$ stretching mode of hydroxyl group, which represents the presence of water molecule on the surface of $\mathrm{ZnO}$ nanoparticles. The small peak between 2830 and $3000 \mathrm{~cm}^{-1}$ are due to $\mathrm{C}-\mathrm{H}$ stretching vibration of alkane groups. Similarly, the band observed at 1630 and $1384 \mathrm{~cm}^{-1}$ are due to asymmetric and symmetric of stretching carbonxylate which attached to the $\mathrm{ZnO}$ nanoparticles during synthesis. The carboxylate probably comes from the reactive carbon containing plasma species during synthesis of $\mathrm{ZnO}$ NPs. As the size of nanoparticles increase the contents of carboxylate groups in the sample decrease as shown in Figure $4 \mathrm{~b}$ and $4 \mathrm{c}$. The sharp peak observed in the range of 433 to $510 \mathrm{~cm}^{-1}$ was attributed to the vibrational phonon of $\mathrm{ZnO}$. This result indicates the successful production of $\mathrm{ZnO}$ nanoparticles [34].

\section{Emission spectra of $\mathrm{ZnO}$ nanoparticles}

Figure $5 \mathrm{a}-5 \mathrm{c}$ shows the emission spectra of $\mathrm{ZnO}$ NPs synthesised using $\mathrm{Zn}\left(\mathrm{CH}_{3} \mathrm{COO}\right)_{2} \cdot 2 \mathrm{H}_{2} \mathrm{O}, \mathrm{ZnCl}_{2}$ and $\mathrm{Zn}\left(\mathrm{NO}_{3}\right)_{2} \cdot 6 \mathrm{H}_{2} \mathrm{O}$ respectively. It is well known that there are two kinds of emission bands of UV and visible spectra in $\mathrm{ZnO}$ crystal. The emission in the UV region is attributed to the recombination between electrons in the conduction band and holes in the valance band [35]. The UV emission of $\mathrm{ZnO}$ NPs synthesised from precursors, $\mathrm{ZnCl}_{2}$ and $\mathrm{Zn}\left(\mathrm{NO}_{3}\right)_{2} \cdot 6 \mathrm{H}_{2} \mathrm{O}$ observed at $325,392 \mathrm{~nm}$ respectively. On the other hand broad band in the visible emission spectra were observed at $455 \mathrm{~nm}$ for precursor $\mathrm{ZnCl}_{2}$, 450, 466481 and $492 \mathrm{~nm}$ for $\left.\mathrm{Zn}\left(\mathrm{NO}_{3}\right)_{2} \cdot 6 \mathrm{H}_{2} \mathrm{O}\right)$ and $435,469 \mathrm{~nm} \mathrm{Zn}$ $\left(\mathrm{CH}_{3} \mathrm{COO}\right)_{2} \cdot 2 \mathrm{H}_{2} \mathrm{O}$ respectively. The visible emission spectra are related to the transition of electron from deep donor level to valence band due to oxygen vacancies and the transition from conduction band to deep acceptor level due to impurities and defect states [35]. The well known stronger and broader emission situated in the UV to blue green emission suggested that the obtained ZnO NPs are high purity and crystalline.
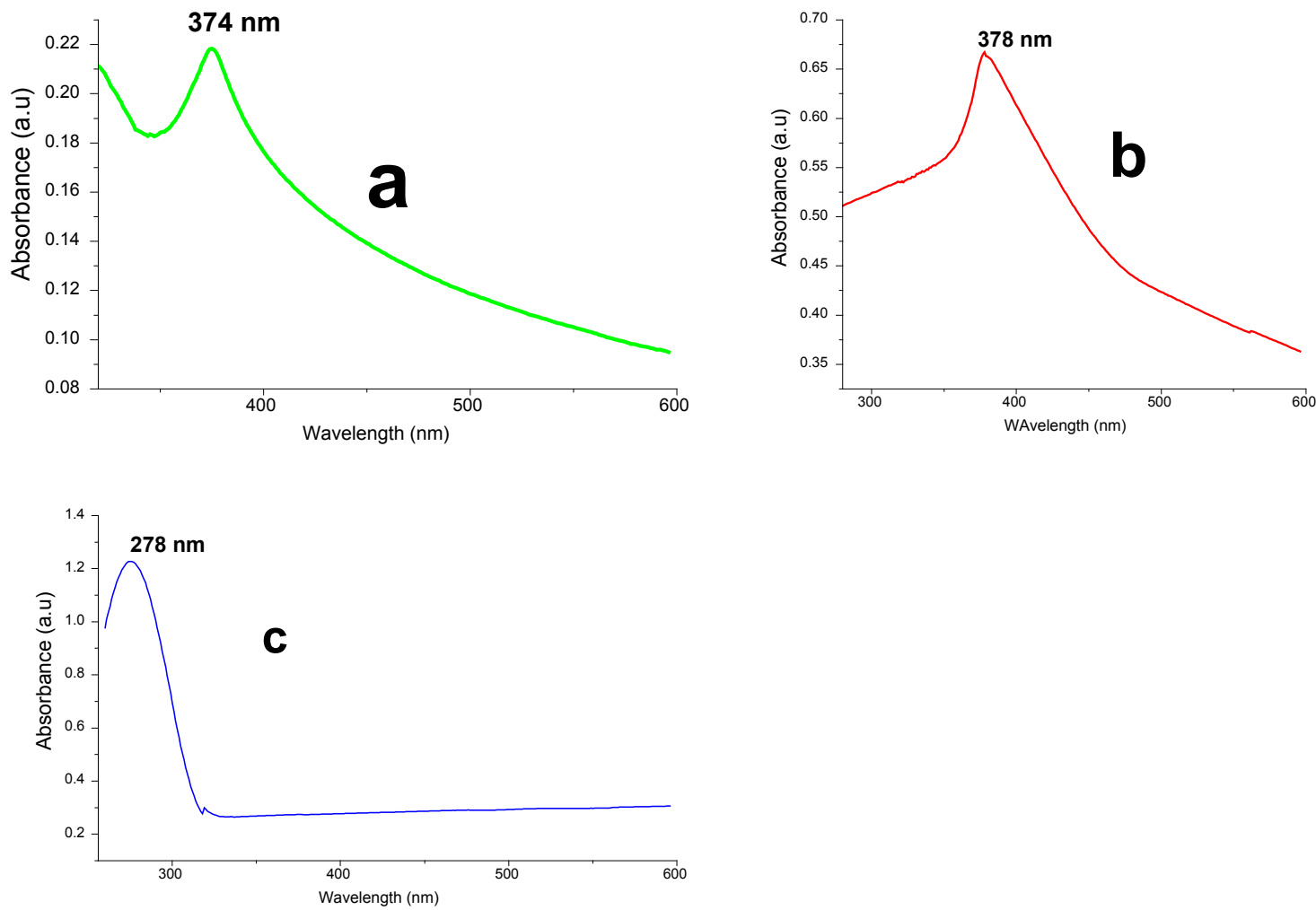

Figure 3: UV-Vis absorption spectra of $\mathrm{ZnO}$ nanoparticles synthesised using a) zinc nitrate hexahydrate, b) zinc acetate dihydrate and c) zinc chloride precursors. 


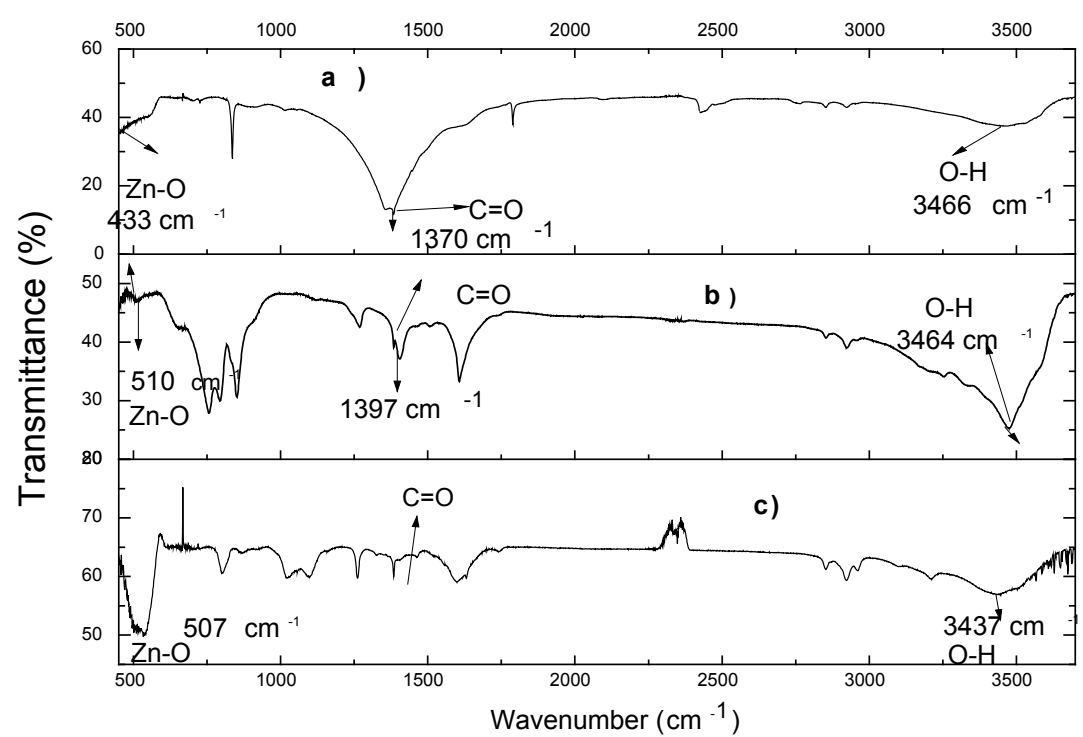

Figure 4: FT IR spectra of $\mathrm{ZnO}$ nanoparticles synthesised using a) zinc nitrate hexahydrate, b) zinc chloride and c) zinc acetate dehydrate.
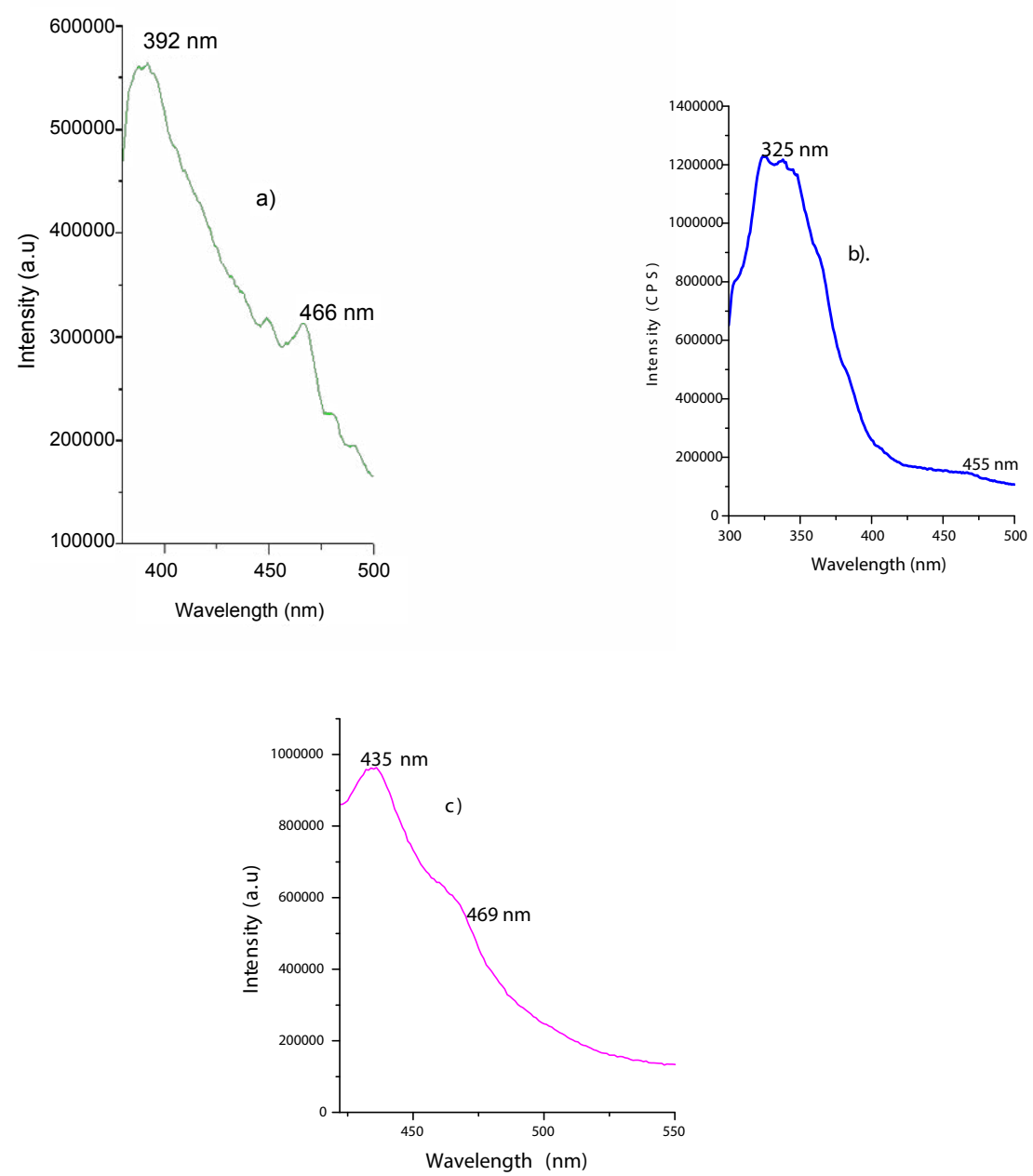

Figure 5: Emission spectra of ZnO nanoparticles synthesised using a) zinc acetate dihydrate, b) zinc chloride and c) zinc nitrate hexahydrate. 
Citation: Getie S, Belay A, Chandra Reddy AR, Belay Z (2017) Synthesis and Characterizations of Zinc Oxide Nanoparticles for Antibacterial Applications. J Nanomedic Nanotechnol S8: 004. doi:10.4172/2157-7439.S8-004

\section{Antibacterial activity of the $\mathrm{ZnO}$ nanoparticles}

Figures $6 \mathrm{a}-6 \mathrm{c}$ shows the antibacterial activity of $\mathrm{ZnO}$ nanoparticles synthesised from $\mathrm{ZnCl}_{2} \mathrm{Zn}\left(\mathrm{NO}_{3}\right)_{2} \cdot 6 \mathrm{H}_{2} \mathrm{O}$ and $\mathrm{Zn}\left(\mathrm{CH}_{3} \mathrm{COO}\right)_{2} \cdot 2 \mathrm{H}_{2} \mathrm{O}$

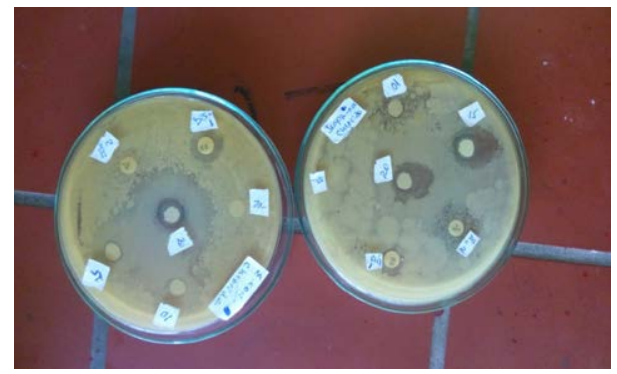

E. coli

S. aureus

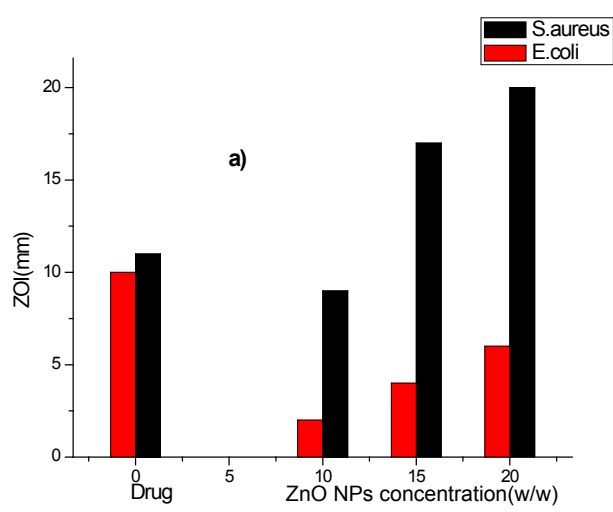

Figure 6a: The comparison of antibacterial activity of ZnO NPs synthesised using zinc chloride on $S$. aureus and $E$. coli.

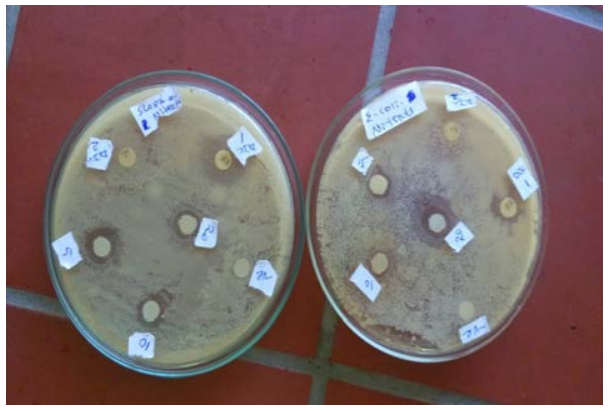

S. aureus

E. coli

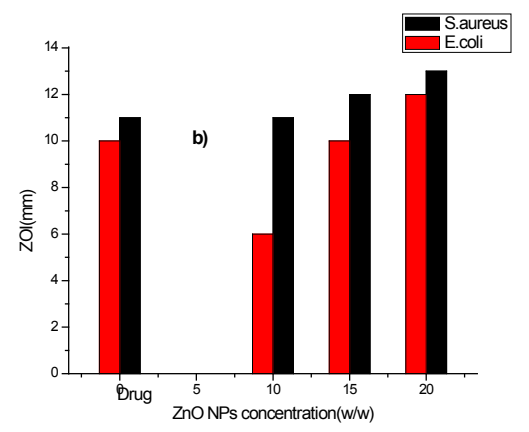

Figure 6b: The comparison of antibacterial activity of ZnO NPs synthesised using zinc nitrate hexahydrate on $S$. aureus and $E$. coli.
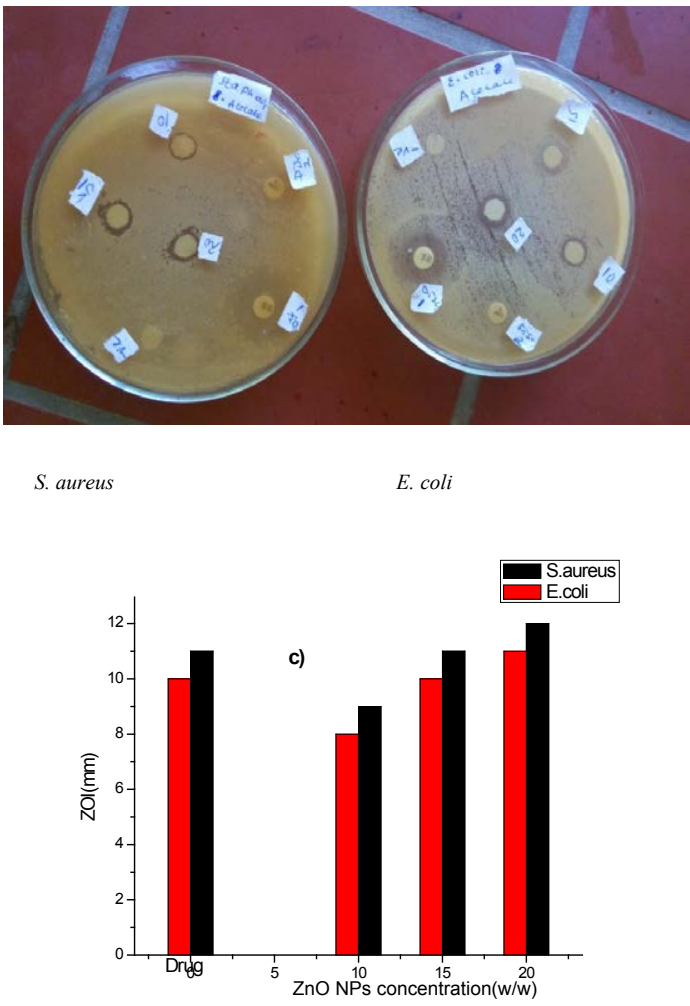

Figure 6c: The comparison of Antibacterial activity of ZnO NPs synthesised using zinc acetate dihydrate on S. aureus and E. coli.

on E. coli and S. aureus bacteria respectively. Antibacterial activity results showed that the $\mathrm{ZnO}$ nanoparticle synthesised using $\mathrm{ZnCl}_{2}$ has exhibited strong antibacterial activity against both gram-positive ( $S$. aureus) and gram-negative (E. coli) bacteria compared to the precursor $\mathrm{Zn}\left(\mathrm{NO}_{3}\right)_{2} \cdot 6 \mathrm{H}_{2} \mathrm{O}$ and $\mathrm{Zn}\left(\mathrm{CH}_{3} \mathrm{COO}\right)_{2} \cdot 2 \mathrm{H}_{2} \mathrm{O}$. Moreover, $\mathrm{ZnO}$ nanoparticles performed better antibacterial activity on gram-positive (S. aureus) than the gram-negative (E. coli) bacteria in comparison to standard antibiotics. The previous research report also indicated antibacterial activity of $\mathrm{ZnO}$ particles were greater on gram-positive than gram-negative bacteria [36,37]. They suggested that the outer thick peptidoglycan layer and other surface components of grampositive bacteria may promote $\mathrm{ZnO}$ attachment onto the cell wall whereas the components of gram-negative bacteria may repeal this attachment. Contrary to this reported [38] investigated that $\mathrm{ZnO}$ particles exhibited a stronger antibacterial activity on gram-negative bacterium than gram-positive bacteria. This discussion points out the importance of understanding the mechanism of $\mathrm{ZnO}$ antimicrobial activity. Generally, the growth inhibition of E. coli and S. aureus has been increased by increasing the concentration of $\mathrm{ZnO}$ nanoparticles in discs. The zone of inhibition produced by $\mathrm{ZnO}$ NPs synthesised using $\mathrm{ZnCl}, \mathrm{Zn}\left(\mathrm{NO}_{3}\right)_{2} \cdot 6 \mathrm{H}_{2} \mathrm{O}$ and $\mathrm{Zn}\left(\mathrm{CH}_{3} \mathrm{COO}\right)_{2} \cdot 2 \mathrm{H}_{2} \mathrm{O}$ against $S$. aureus and E. coli is given in Figure $4 \mathrm{a}-4 \mathrm{c}$ respectively.

\section{Conclusions}

Zinc oxide nanoparticles have been synthesised using zinc acetate dihydrate, zinc chloride and zinc nitrate hexahydrate as a precursor via a wet chemical method. The synthesised $\mathrm{ZnO}$ nanoparticles were characterised by X-ray diffraction (XRD), Scanning Electron Microscopy (SEM), UV-Vis Spectroscopy, Fluorescence Spectroscopy and FTIR Spectroscopy. The averaged crystallite size of unmodified 
Citation: Getie S, Belay A, Chandra Reddy AR, Belay Z (2017) Synthesis and Characterizations of Zinc Oxide Nanoparticles for Antibacteria Applications. J Nanomedic Nanotechnol S8: 004. doi:10.4172/2157-7439.S8-004

$\mathrm{ZnO}$ nanoparticles synthesised using zinc nitrate hexahydrate and zinc acetate dihydrate was about $28.09 \mathrm{~nm}$ and $31.86 \mathrm{~nm}$ respectively. The use of different salt precursors and calcination temperature leads to change in the particle size and shape of nanoparticles. The variation in UV-Vis absorption peaks of $\mathrm{ZnO}$ NPs indicates that the optical property of ZnO NPs is highly influenced by their shape and size. The vibrational phonon of $\mathrm{ZnO}$ observed in the range of $433 \mathrm{~cm}^{-1}-510 \mathrm{~cm}^{-1}$ confirms the successful production of $\mathrm{ZnO}$ NPs. The $\mathrm{ZnO}$ nanoparticles showed two emission bands, an ultraviolet (UV) emission band due to the electronic transition from conduction band edge to valence band, and visible emission band due to defects that are related to deep level emissions. The adsorption of negatively charged caffeine on to $\mathrm{ZnO}$ NPs leads to dispersion of already aggregated nanoparticles. The synthesised $\mathrm{ZnO}$ NPs were also applied for antibacterial applications. All the three $\mathrm{ZnO}$ NPs have been shown admirable antibacterial activity compared to the standard antibiotic drugs on S. aureus. However, the $\mathrm{ZnO} \mathrm{NP}$ synthesised using a precursor $\mathrm{ZnCl}_{2}$ was revealed excellent antibacterial activity than the two precursors against both $S$. aureus and E. coli. Generally, the result in this study indicates that $\mathrm{ZnO}$ nanoparticles are more effective against Gram-positive (S. aureus) compared to Gram-negative (E. coli) suggesting that selective action of the $\mathrm{ZnO}$ against biological systems.

\section{Acknowledgments}

The authors would like to acknowledge Adama Science and Technology University and Ministry of Science and Technology of Ethiopia for financial support and National Institute of Technology, Physics Department, India for allowing us to use the XRD for characterization of our samples and also Pusan Nationa University, Department of Nanoscience and Nanotechnology, South Korea for allowing us to use SEM.

\section{References}

1. Segets D, Gradl J, Taylor RK, Vassilev V, Peukert W (2009) Analysis of optical absorbance spectra for the determination of $\mathrm{ZnO}$ nanoparticle size distribution, solubility, and surface energy. ACS Nano 3: 1703-1710.

2. Lou X (1991) Development of $\mathrm{ZnO}$ series ceramic semiconductor gas sensors J Sens Trans Technol 3: 1-5

3. Bacaksiz E, Parlak M, Tomakin M, Özcelik A, Karakiz M, et al. (2008) The effect of zinc nitrate, zinc acetate and zinc chloride precursors on investigation of structural and optical properties of $\mathrm{ZnO}$ thin films. J Alloy Compd 466: 447-450.

4. Wang J, Cao J, Fang B, Lu P, Deng S, et al. (2005) Synthesis and characterization of multipod, flower-like, and shuttle-like $\mathrm{ZnO}$ frameworks in ionic liquids. Mater Lett 59: 1405-1408.

5. Wang ZL (2008) Splendid one-dimensional nanostructures of zinc oxide: A new nanomaterial family for nanotechnology. ACS Nano 2: 1987-1992.

6. Chaari M, Matoussi A (2012) Electrical conduction and dielectric studies of $\mathrm{ZnO}$ pellets. Phys B Condens Matter 407: 3441-3447.

7. Özgür Ü, Alivov YI, Liu C, Teke A, Reshchikov MA, et al. (2005) Comprehensive review of $\mathrm{ZnO}$ materials and devices. J Appl Phys.

8. Bhattacharyya S, Gedanken A (2008) A template-free, sonochemical route to porous ZnO nano-disks. Microporous Mesoporous Mater 110: 553-559.

9. Ludi B, Niederberger M (2013) Zinc oxide nanoparticles: Chemical mechanism and classical and non-classical crystallization. Dalton Trans 42: 12554-12568.

10. Masaki T, Kim SJ, Watanabe H (2003) Synthesis of Nano-Sized ZnO Powders Prepared by Precursor Process. J Ceram Process Res. 4: 135-139.

11. Chen L, Chen Z, Shang $X Z$ (2006) Effect of annealing temperature on density of $\mathrm{ZnO}$ quantum dots. Solid State Commun 137: 561-565.

12. Wang ZL (2004) Zinc oxide nanostructures: growth, properties and applications J Phys Condens Matter 16: R829-R858.

13. Wu HZ, Qiu DJ, Cai YJ (2002) Optical studies of $\mathrm{ZnO}$ quantum dots grown on $\mathrm{Si}\left(\begin{array}{lll}0 & 0 & 1\end{array}\right)$. J Cryst Growth 245: 50-55.
14. Yang LL, Yang JH, Liu XY (2008) Low-temperature synthesis and characterization of $\mathrm{ZnO}$ quantum dots. J Alloys Compd 463: 92-95.

15. Wu YL, Tok AlY, Boey FYC (2007) Surface modification of ZnO nanocrystals. Appl Surf Sci 253: 5473-5479.

16. Guo L, Yang SH, Yang CL (2000) Highly monodisperse polymer-capped ZnO nanoparticles: Preparation and optical properties. Appl Phys Lett 76: 29012903

17. Tong YH, Liu YC, Lu SX (2004) The Optical Properties of ZnO Nanoparticles Capped with Polyvinyl Butyral. J Sol Gel Sci Technol 30: 157-161.

18. Brayner R, Ferrari-lliou R, Brivois N, Djediat S, Benedetti MF, et al. (2006) Toxicological impact studies based on escherichia coli Bacteria in ultrafine $\mathrm{ZnO}$ nanoparticles colloidal medium. Nano Lett 6: 866-870.

19. Zhang L, Jiang Y, Ding Y, Povey M, York D (2007) Investigation into the antibacterial behaviour of suspensions of $\mathrm{ZnO}$ nanoparticles ( $\mathrm{ZnO}$ nanofluids) J Nanopart Res 9: 479-489.

20. Roselli M, Finamore A, Garaguso I, Britti MS, Mengheri E (2003) Zinc oxide protects cultured enterocytes from the damage induced by Escherichia coli. $J$ Nutr 133: 4077-4082.

21. Zhang L, Ding Y, Povey M, York D (2008) ZnO nanofluids - A potential antibacterial agent. Progress Nat Sci 18: 939-944.

22. Stoimenov PK, Klinger RL, Marchin GL, Klabunde KJ (2002) Metal oxide nanoparticles as bactericidal agents. Langmuir 18: 6679-6686.

23. Jones N, Ray B, Koodali TR, Manna AC (2008) Antibacterial activity of ZnO nanoparticle suspensions on a broad spectrum of microorganisms. FEMS Microbio Lett 279: 71-76

24. Premanathan M, Karthikeyan K, Jeyasubramanian K, Manivannan G (2011) Selective toxicity of $\mathrm{ZnO}$ nanoparticles toward Gram-positive bacteria and cancer cells by apoptosis through lipid peroxidation. Nanomedicine: Nanotechnology, Biology and Medicine 7: 184-192.

25. Murty BS, Shankar P, Raj B, Rath BB, Murday J (2013) Covers fundamental aspects of nanoscience and technology. Berlin, Germany.

26. Marivone G, Jeane AR, Gilvan SB, Carlos EMC, Humberto GR, et al. (2011) Synthesis of $\mathrm{ZnO}$ nanostructures in low reaction temperature. Florianópolis, SC, Brasil.

27. Parthsarathi V, Thilagawathi G (2011) Synthesis and characterization of zinc oxide nanoparticle and its application on fabrics for microbe resistant defence clothing. International Journal of Pharmaceutical Sciences 3: 392-398.

28. Rajneesh KS, Sheo KM, Prakash SG (2012) ZnO nanoparticles: Structural, optical and photoconductivity characteristics. Journal of Alloys and Compounds 539: 1-6.

29. Sawai J (2003) Quantitative evaluation of antibacterial activities of metallic oxide powders $(\mathrm{ZnO}, \mathrm{MgO}$ and $\mathrm{CaO})$ by conductimetric assay. Journal of Microbiological Methods 54: 177-182.

30. Suhandro PP, Rosari S (2012) Synthesis and spectroscopic characterization of undoped nanocrystalline $\mathrm{ZnO}$ nanoparticles prepared by co-precipitation. Journal of Material Science and Applications 3: 530-537.

31. Mayekar J, Dhar V, Radha S (2014) Role of salt precursor in the synthesis of zinc oxide nanoparticles. International Journal of Research in Engineering and Technology 3: 43-45

32. Banwell CN, McCash EM (1999) Fundamentals of molecular spectroscopy (4thedn), McGraw-Hill International, UK.

33. Imran K (2013) Structural and optical properties of $\mathrm{Zr}$ doped $\mathrm{ZnO}$ nanoparticles. Optmater 35: 1189-1193.

34. West AR (2003) Solid state chemistry and its applications. John Wiley\&Sons Singapore, Indian

35. Irimpan L, Nampoori VPN, Radhakrishnan P, Deepthy A, Krishnan B (2007) Size dependent fluorescence spectroscopy of nanocolloids of $\mathrm{ZnO}$. Journal of Applied Physics 102: 1-7.

36. Reddy KM, Feris K, Bell J, Wingett DG, Hanley C, et al. (2007) Selective toxicity of zinc oxide nanoparticles to prokaryotic and eukaryotic systems. Appl Phys Lett. 
Citation: Getie S, Belay A, Chandra Reddy AR, Belay Z (2017) Synthesis and Characterizations of Zinc Oxide Nanoparticles for Antibacterial Applications. J Nanomedic Nanotechnol S8: 004. doi:10.4172/2157-7439.S8-004

Page 8 of 8

37. Tayel AA, El-Tras WF, Moussa S, El-Baz AF, Mahrous H, et al. (2011) Antibacterial action of zinc oxide nanoparticles against foodbornepathogens. J Food Safety 31: 211-218.
38. Pasqueta J, Chevalierb Y, Couvala E, Bouviera D, Noizeta G, et al. (2014) Anticrobial activity of zinc oxide particles on five micro-organisms of the Challenge Tests related to their physicochemical properties. International Journal of Pharmaceutics 460: 92-100. 